Petar Mišević

University North

42000 Varaždin, Croatia

pmisevic@unin.hr
JEL: F18, O18, R11, F15

Preliminary communication

https://doi.org/10.51680/ev.34.1.14

Received: October 2, 2020

Accepted for publishing: October 31, 2020

This work is licensed under a

Creative Commons Attribution-

NonCommercial-NoDerivatives 4.0 International License

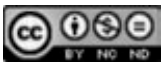
Wr No

\title{
INTERNATIONAL TRADE OF THE EURASIAN ECONOMIC UNION (EAEU)
}

\begin{abstract}
Purpose: The main purpose of this research is to analyse the international trade of the EAEU member states.

Methodology: The paper is based on the use of indicators such as the trade balance, intra-industry trade, import content of exports, trade openness, and the share of exports in GDP.

Results: The results show openness to foreign trade and export orientation of the EAEU member states.

Conclusion: The conclusion is that international trade, the rapid growth of export, and trade openness differ significantly between the EAEU member states.
\end{abstract}

Keywords: International trade, EAEU, global trade indicators

\section{Introduction}

The Eurasian Economic Union (hereinafter: the EAEU or the Union) is an international organisation for regional economic integration. It has international legal personality and was established by the Treaty on the Eurasian Economic Union. The EAEU provides for free movement of goods, services, capital and labour, pursues coordinated, harmonised and single policy in the sectors determined by the Treaty and international agreements within the Union. The Member States of the Eurasian Economic Union are the Republic of Armenia, the Republic of Belarus, the Republic of Kazakhstan, the Kyrgyz Republic and the Russian Federation. The Union was created to comprehensively modernise and raise the competitiveness and cooperation of national econo- mies, and to promote stable development aimed at increasing the standard of living of the Member States' nations (EAEUNION, 2020).

The Eurasian Economic Union is a young international organisation of regional economic integration that was established by Belarus, Kazakhstan and Russia in 2015 (Eurasian Studies, 2020) ${ }^{1}$.

Today, the Union comprises five member states (Armenia, Belarus, Kazakhstan, Kyrgyzstan and Russia) that have committed to pursue the following objectives (Treaty on the Eurasian Economic Union, 2014) $)^{2}$ :

\footnotetext{
1 Eurasian Studies (2020), available at: http://eurasian-studies. org/archives/2955

2 Treaty on the Eurasian Economic Union (2014)
} 
- to create conditions for the sustainable economic development of the Member States to improve the living standards of their population;

- to seek to create a common market for goods, services, capital and labour within the Union;

- to ensure comprehensive modernisation, cooperation and competitiveness of national economies within the global economy.

The three founding states make an "integration core" of Eurasian integration (Vinokurov, 2014), and several multilateral treaties regulate their economic relations. The idea of regional economic integration in Eurasia dates back to 1994 when President Nursultan Nazarbayev of Kazakhstan first introduced the initiative to establish a Eurasian Union with a focus on the economy.

In 1995, Belarus, Kazakhstan and Russia signed the Customs Union Treaty. The document envisaged removing barriers to free cooperation between the countries' commercial enterprises, promoting free trade, and fair competition (Vinokurov \& Tsukarev, 2015). Kyrgyzstan and Tajikistan signed this Agreement in 1996. However, their commitments to lift non-tariff barriers and unify tariffs for members of the Customs Union were not put into practice, since the countries were deeply divided on economic and political issues.

In 2000, Belarus, Kazakhstan, Kyrgyzstan, Russia and Tajikistan established the Eurasian Economic Community (EurAsEC) to formalise the free trade regime and establish a unified system of customs regulation (Eurasian Studies, 2020). In 2007, Russia, Belarus and Kazakhstan signed the Treaty on the Creation of the Common Customs Territory and Establishment of the Customs Union (2020) ${ }^{3}$. An action plan was adopted to provide for the free movement of goods among the members and to facilitate trade with third countries.

In 2009, Belarus, Kazakhstan and Russia set up the Customs Union (CU). As a result, a single customs territory was created, border control was eliminated, and a single customs tariff took effect. In 2012, the CU expanded and became the Single Economic Space (SES). The three states agreed to coordinate a

3 World Intellectual Property Organization (2020), "Agreement on the Creation of Common Customs Territory and Establishing of Customs Union", available at: http://www. wipo.int/wipolex/en/other_treaties/text.jsp?file_id=330115 number of key issues, from macroeconomic policy to labour migration.

Finally, the Treaty on the Eurasian Economic Union came into force on January 1, 2015. Armenia joined the integration project on 2 January 2015, followed by the Kyrgyz Republic in May 2015. The core of this integration project is the creation of a single market for goods, services, capital, and labour (Vinokurov \& Tsukarev, 2015). The EAEU has attracted strong criticism because many scholars argue that this Union is a "Russia-dominated organisation" (Van der Togt, 2015, p. 52) and that it is "too weighted in favour of Russia” (Popescu, 2014, p. 11).

In 2016, the Agreement on the Free Trade Area between the EAEU and Vietnam entered into force. The Agreement mainly pursues mutual abolition of trade duties. In December 2016, the Heads of States signed the Declaration on the Union's Digital Agen$\mathrm{da}$, which laid the foundation for the development of integration in the digital sphere. At the beginning of 2017, the White Paper was published, a manifesto that determined the top priority areas of the Eurasian Economic Commission's work on identifying and eliminating obstacles in the Union's internal market (EURASIAN COMMISSION, 2020) ${ }^{4}$.

On April 11, 2017, the Presidents of the Union States signed the Treaty on the Customs Code of the Eurasian Economic Union. In April 2017, plans for liberalisation of services entered into force, whereby another 20 service sectors were to join the single market format before 2021, including highly dangerous construction works, tourism, assessment, mine surveying, and scientific research.

In 2018, the Interim Agreement leading to the formation of a free trade area was signed between the Eurasian Economic Union and the Islamic Republic of Iran during the Astana Economic Forum. The Agreement on Trade and Economic Cooperation between the EAEU and the People's Republic of China was also signed (EURASIAN COMMISSION, 2020).

In terms of international trade of the EAEU, in the period from January-June 2018, the prevailing goods in the export commodity structure of the EAEU Member States to third countries included mineral products $(67.2 \%$ of the total export volume of the EAEU Member States to third countries), metals and metal products (10.4\%), and chemical industry products (5.7\%). About $80 \%$ of these goods were sold by the Russian Federation at foreign mar-

\footnotetext{
4 EURASIAN COMMISSION (2020), available at: http://www. eurasiancommission.org/ru/Documents/2797_1_EEK_\%Do \%A6\%D०\%98\%D०\%A4\%D०\%Ao_\%Do\%Bo\%Do\%BD\%Do \%B3\%Do\%BB_sait_rasv.pdf
} 
kets. The largest share of imports was machinery, equipment and vehicles (43.7\% of total imports), chemical industry products (18.8\%), and food products and agricultural stock (12.3\%). More than $80 \%$ of such goods outside the EAEU were purchased by the Russian Federation.

According to the International Crisis Group (ICG, 2020), the initial establishment of the Customs Union coincided with an intra-regional trade increase by 32.1 per cent in 2011 to some $\$ 62$ billion, and by a further 7.5 per cent in 2012. Since then, a strong downward trend had been observed, falling by 5.5 per cent in 2013, 11 per cent in 2014, and 25.8 per cent in 2015 . By the year 2015, trade among EAEU members was down to $\$ 45$ billion. In the period from January-April 2016, trade was down by 18.4 per cent, year-on-year. Foreign trade outside the EAEU had also been in decline for the bloc since 2012, shrinking by 34 per cent in 2015 . It is difficult to assess the EAEU's direct impact on the trade because its introduction coincided with an economic slowdown in Russia and Kazakhstan and sharp currency devaluations. Above all, the decrease in oil and commodity prices skewed figures sharply downwards (mineral resources constituted two-thirds of EAEU exports and one-third of trade within the EAEU in 2015). As a result, the foreign trade for EAEU members dropped with all major partners, both within and outside the EAEU.

Today, the primary objectives of the EAEU include making its market more attractive for local and foreign investors and creating a network of freetrade agreements, including two essential trade and investment partners, the EU and China (Eurasian Studies, 2020). Of course, we need to bear in mind that COVID-19 situation has slowed down both the economic growth and international trade growth.

The main aim of this research is to analyse and present the international trade of five EAEU member states, i.e. Belarus, Kazakhstan, Russia, Kyrgyzstan and Armenia. The foreign trade of these five countries will be analysed using selected foreign trade indicators.

The main premise of this paper assumes differences in trade openness and export orientation between the EAEU member states. The paper begins with an introduction, followed by methodological frameworks containing the mathematical equations of the applied indicators. The third part contains the results of the research and the analysis of the EAEU countries' international trade. The paper ends with a conclusion in which the relevant findings are presented. Recommendations are given concerning the improvement of the EAEU countries' foreign trade.

\section{Methodology}

For the purpose of this paper, an analysis is conducted of the relevant foreign trade indicators calculated based on the data from World Bank statistical database $(2020)^{5}$. The following indicators were separately calculated and analysed: intra-industry trade, trade balance, export-import ratio, trade openness and share of exports in GDP for the five EAEU member states for the period from 2014 to 2018. Methodological frameworks are adopted from works by Kandžija et al. (2014), Bezić and Galović (2014), Galović et al. (2017), Galović et al. (2018), Mišević (2019).

Trade is generally viewed as essential for a country's growth and, to some level, its economic development. Krugman (1983) and Bhagwati (2004) pointed out other benefits of trade, such as its importance for increasing employment, poverty reduction, income reallocation and economic growth. Solow (1956) likewise notes that the market-centred trade liberalisation accelerates economic growth and development.

An index that measures intra-industry trade was first developed by Balassa, who defined it as the index that tracks the degree to which an industry's export value matches its import value (Balassa, 1966). Based on Balassa's research, Grubel and Lloyd (1975) further developed their model. They indicate that the products in horizontal intra-industry trade are similar, while the vertical intra-industry trade consists of products with different levels of quality. Furthermore, several pieces of research of the factors that influence the success or failure of efforts to promote industrialisation and growth conclude that the growing level of intra-industry trade is highly significant (World Bank, 2018) ${ }^{6}$.

The intra-industry trade brings additional benefits from international trade beyond those associated with comparative advantages. It allows the country to take advantage of broader markets. Intraindustry trade (IITR) is the value of total trade that remains after deducting the absolute value of a country's net exports or imports. For a comparison between countries and industries, measures are expressed as a percentage of exports and imports of each sector. Index values vary between 0 and 100 . The closer the values are to 100 , the more imported and exported products come from the same industry. If a country exports and imports approximately equal quantities of a particular product, the value of the index is high.

\footnotetext{
5 World Bank (2020), available at: https://databank.worldbank.org 6 World Bank (2018), available at: https://databank.worldbank.org
} 
Some studies have investigated intra-industry trade of free trade areas. Authors like Mardas and Nikas (2008) analyse the free trade areas between the Balkan countries and Greece. The authors emphasise that trade liberalisation contributed to intra-industry trade. Recent studies have found that vertical intra-industry trade dominates horizontal intraindustry trade in bilateral trade. Wakasugi (2007) developed an index of vertical intra-industry trade to calculate the fragmentation of production. The author implemented a gravity model and analysed the impact of intra-industry trade in East Asia, free trade areas like NAFTA, and the European Union. He concluded that fragmentation had improved with the intra-industry trade.

If the trade is mostly one-way (export or import), the value of the index is low. The indicator equation is expressed as follows:

$$
\operatorname{IITR}_{i}=1-\left(1-\frac{\text { expo }_{i}-\text { impo }_{i} \mid}{\operatorname{expo~}_{i}+\text { impo }_{i}}\right) \check{A}-100
$$

\section{Where:}

expo $_{i}$ - export activities of the country " $i$ " impo $o_{i}$ - import activities of the country " $i$ "

Current account imbalances remain substantial across the globe, creating the risks of protectionism and financial vulnerabilities if suddenly the capital flows financing these imbalances dry up (Kharroubi, 2011). According to the same author, based on the experience of OECD countries over the last 20 years, globalisation has affected the relationship between the real exchange rates and trade balances in two aspects. From one perspective, the development of international trade from within has led countries to trade similar types of goods, as opposed to trading between various industries. This has raised the substitutability between the types of goods imported and exported and thereby increased the sensitivity of the trade balance to the real exchange rate. On the other hand, the development of global supply chains and vertical specialisation across countries has raised the complementarity between the types of goods imported and exported, thereby reducing the sensitivity of the trade balance to the real exchange rate.

The next indicator analysed in the paper is the trade balance indicator (TBAL). TBAL is calculated as the difference between the value of imports and exports of goods and services. The calculation is based on the real values of national currencies. This indicator is used in macroeconomic surveys to measure sectoral competitiveness or the competitiveness of the economy. When a country's imports of goods and services exceed its exports, we talk about a trade deficit. When the opposite is true, trade surplus occurs.

TBAL is calculated according to the following equation:

$$
\mathrm{TBAL}_{i}=\operatorname{expo}_{i}-\text { impo }_{i}
$$

Where:

expo $_{i}$ - export activities of the country " $i$ "

impo $_{i}$ - import activities of the country " $i$ "

The export-to-import ratio (EXIM) is the ratio of exports to imports, the result of which is expressed as a percentage. The following equation defines the EXIM indicator:

$$
\mathrm{EXIM}_{i}=\frac{\operatorname{expo}_{i}}{\operatorname{impo}_{i}} \times 100
$$

\section{Where:}

$\operatorname{expo}_{i}$ - export activities of the country " $i$ " impo $_{i}$ - import activities of the country " $i$ "

According to Fujii (2017), an empirical measure of trade openness is defined as the ratio of total trade to GDP; it represents a convenient variable routinely used in cross-country studies on a number of topics. The size of trade in relative terms to GDP depends on a variety of factors. In addition to the extent of the outward orientation of trade policy, they include the sizes of the domestic and external markets, the distances to consumers and from producers outside one's territory, factor endowments that induce specialisation in production, and households' preferences for a variety in consumption. Fujii (2017) notes that as a composite of the numerous factors, the empirical measure of trade openness, as convenient as it may be, inflicts difficulty on the interpretation of its effects as documented in various contexts.

The degree of trade openness is a measure of the openness of an economy. It is argued that trade openness brings several economic benefits, including increased technology transfer, skills transfer, labour force growth, total-factor productivity, and economic growth and development. It is calculated as the sum of the values of realised exports and imports in relation to the realised gross domestic product in a certain period.

$$
\mathrm{TOI}_{\mathrm{i}}=\frac{\text { expo }_{\mathrm{i}}+\mathrm{impo}_{\mathrm{i}}}{\mathrm{GDP}}
$$

\section{Where:}

expo $_{i}$ - export activities of the country " $i$ " 
impo - import activities of the country " $i$ "

$G D P$ - the gross domestic product of the observed country

The increase in the sum of exports and imports in the gross domestic product for the observed period indicates a greater degree of openness of the economy and implies rising international foreign trade flows. Indicators that measure the degree of transparency of countries clearly show the stability and participation of the foreign trade sector in foreign trade flows.

When measuring export expansion, the following elements are considered:

$$
\mathrm{EGDP}_{\mathrm{i}}=\frac{\text { expo }}{\mathrm{GDP}}
$$

Where:

expo - the export activity of country " $i$ "

$G D P$ - the gross domestic product of the observed country
The growth of the share of merchandise exports in gross domestic product in a certain period indicates a higher expansion of an economy's exports. In contrast, the decline in the share of merchandise exports in an economy's GDP represents a lower export expansion.

The above-mentioned indicators provide the theoretical background and the basis for analysing the international trade and competitiveness of the five EAEU countries.

\section{Research results}

The results for intra-industry trade, trade balance, export-import ratio, trade openness, and the share of exports in GDP are given for all five EAEU countries for the period 2014-2018.

Figure 1 shows the results for intra-industry trade between the EAEU countries.

\section{Figure 1 Intra-industry trade (IITR) indicator for EAEU countries, 2014-2018}

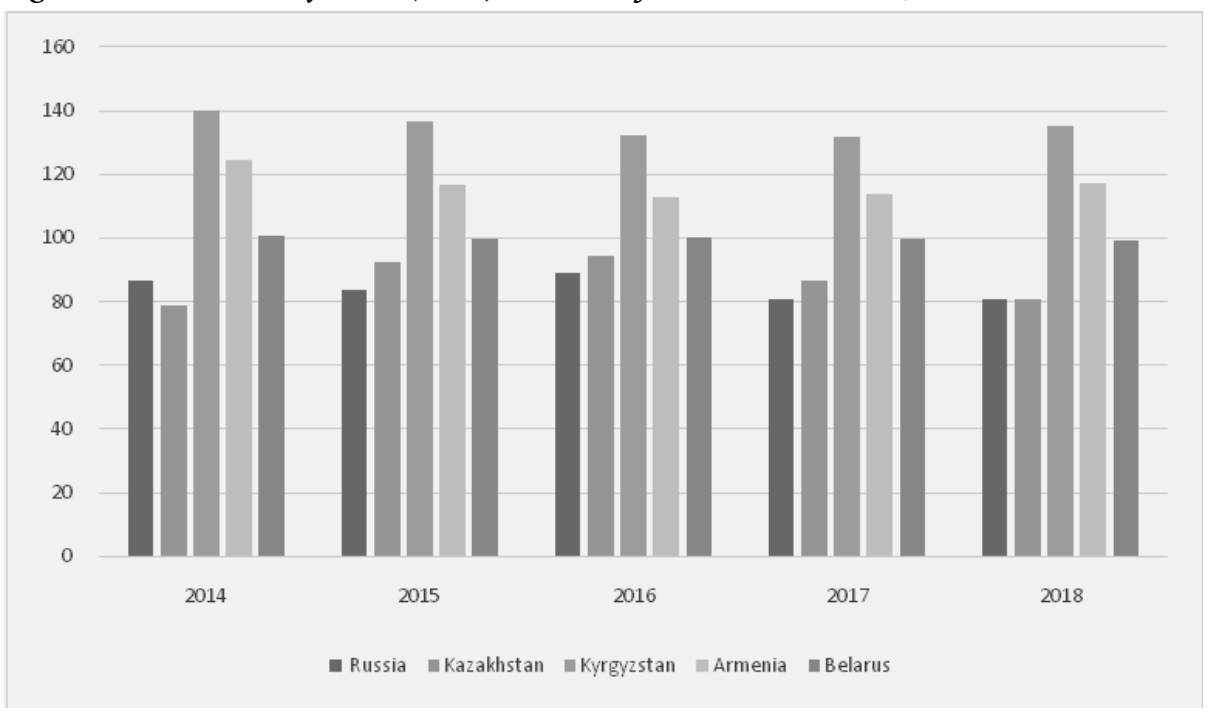

Source: Author's representation according to the World Bank statistical database (2020) data

As can be seen from Figure 1, the results for intraindustry trade show similar levels across the EAEU countries. The dynamics of the intra-industry trade indicator are identical for each chosen country as well. As is evident from Figure 1, high IITR values were recorded for all EAEU member states. It is of note that Russia's IITR level ranged between $80-88 \%$ during the observed period. Russia is a significant exporter of oil and natural gas. Kazakhstan record- ed similar levels and trends in IITR indicators to those of Russia. Kyrgyzstan, Armenia and Belarus are characterised by far higher levels of IITR indicators, which indicate a one-way exchange. Figure 2 will show whether this is predominantly an import or export activity.

Figure 2 shows the foreign trade balance of the EAEU countries in the period from 2014 to 2018. 
Figure 2 Foreign Trade Balance (TBAL) indicator for EAEU countries, 2014-2018

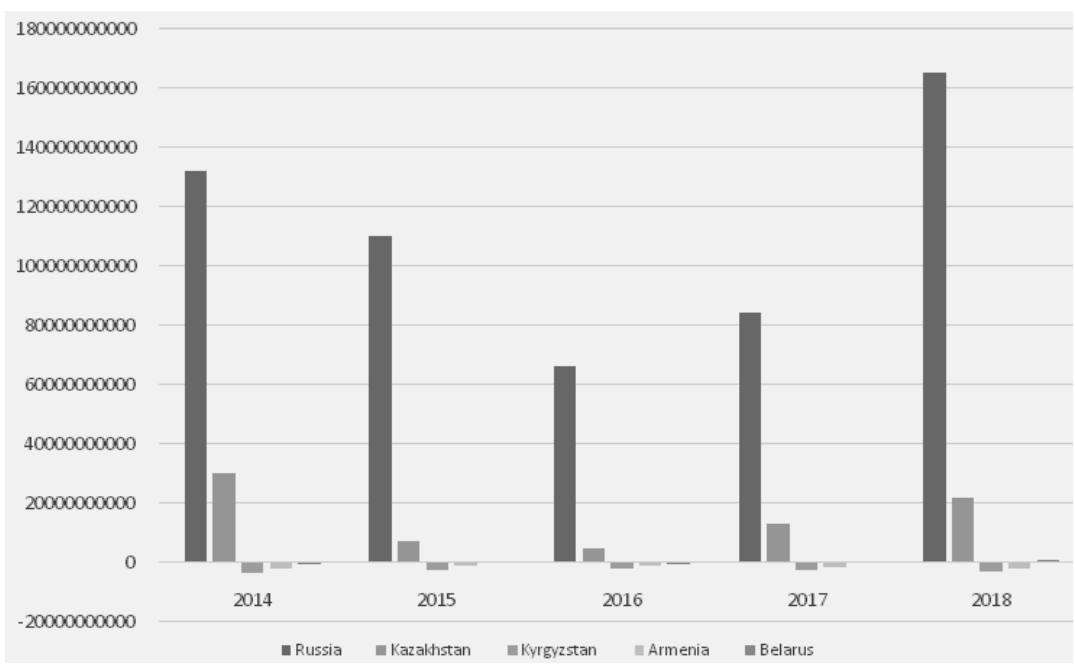

Source: Author's representation according to the World Bank statistical database (2020) data

It is clear from Figure 2 that there are significant differences in international competitiveness between the EAEU member states. A volatile trend in trade surplus is evident for Russia and Kazakhstan. The decline in Russia's trade surplus was caused by the economic slowdown between 2014 and 2015, that is, the fall in crude oil prices and the devaluation of the Russian Rouble. In 2018, trade with Russia accounted for $96.9 \%$ of total trade within the EAEU, indicating Russia's dominant role in EAEU trade. Kazakhstan's main export products were also oil and gas, whose prices have significantly affected its trade balance over the observed period.

The remaining EAEU countries faced a trade deficit throughout the observed period, except for Belarus, which recorded a trade surplus in 2014 and 2016. The largest deficit was recorded by Kyrgyzstan.

Figure 3 is a graphical representation of the results of the export-import ratio for EAEU countries.

Figure 3 Import content of exports (EXIM) for the EAEU countries, 2014-2018

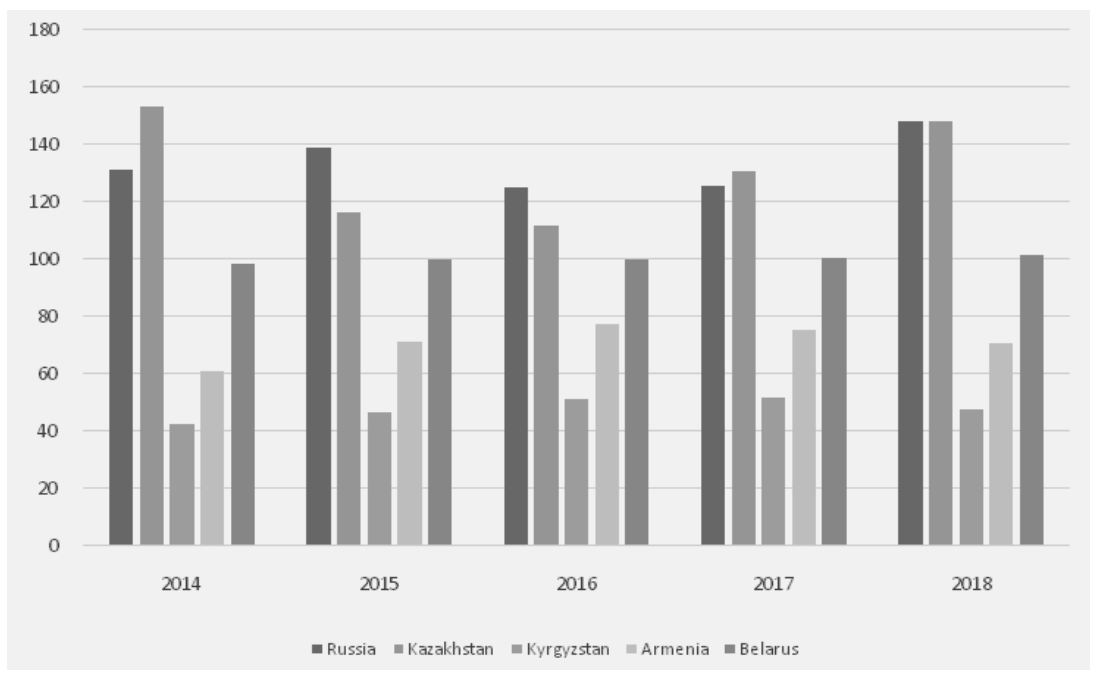

Source: Author's representation according to the World Bank statistical database (2020) data 
The economies of Russia and Kazakhstan are undoubtedly dependent on their export activity. Belarus can also be classified as an export-oriented country. In other words, the Belarusian economy relies heavily on exports into more than 170 countries with which it has established trade ties. It should be noted that Belarus is the world's thirdlargest producer of potassium raw materials used in many fertilisers and chemical products. Russia is Belarus' main trading partner, i.e. the largest recipient of its exports (almost half of total exports), which include mainly minerals, chemicals, machinery and food. The EU imports more than a third of its exports, which include petrochemicals, fertilisers and textiles. Belarus' imports include mainly energy products from Russia, i.e. oil and gas, and raw materials.
It should be mentioned that Belarus is deeply integrated with the EAEU in terms of trade. Approximately $51 \%$ of Belarus' total foreign trade is with other ERP members (mostly Russia) - although this percentage is lower than it used to be at the turn of the millennium (60\%). The values of the EXIM index for Russia and Kazakhstan exceeded 100\% throughout the observed period, which indicates the dominant role of exports over imports. In contrast, Kyrgyzstan and Armenia imported significantly more than they exported, as evident from their import content of exports, while the values of the EXIM indicator for Belarus ranged between $98 \%$ and $101 \%$.

The degree of openness of the EAEU countries is shown in Figure 4.

\section{Figure 4 Trade Openness Index (TOI) for the EAEU countries, 2014-2018}

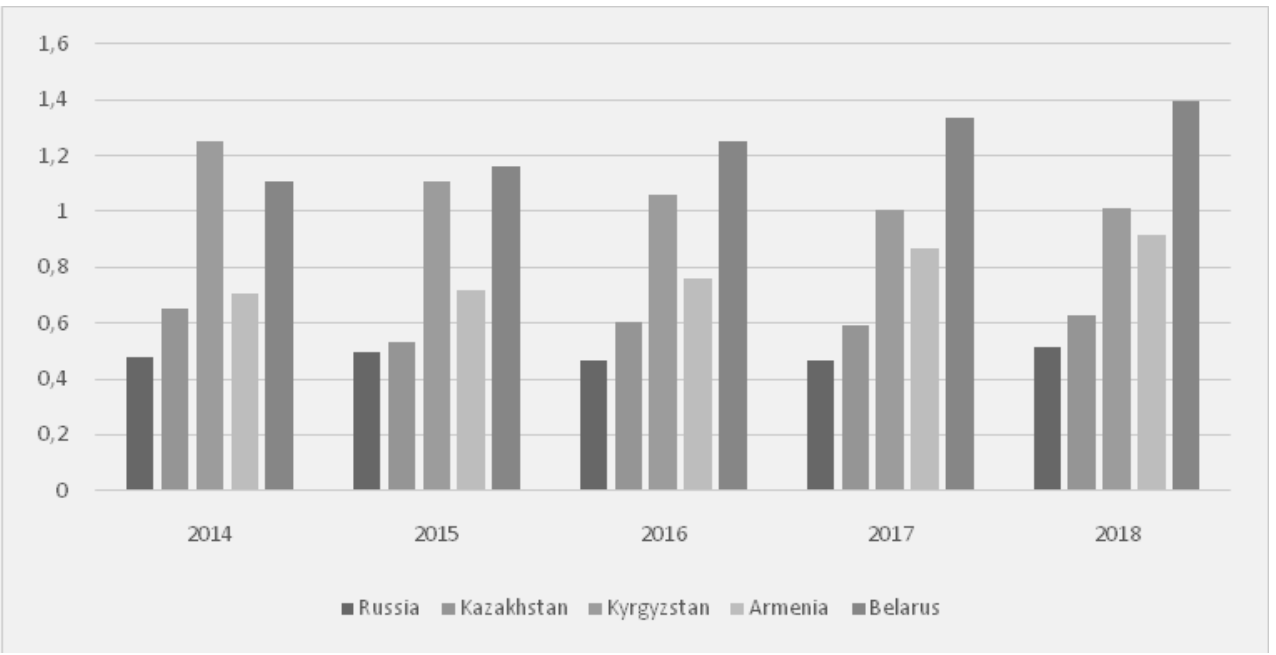

Source: Author's representation according to the World Bank statistical database (2020) data

It is apparent from Figure 4 that Belarus and Kyrgyzstan have the highest trade openness indices in the EAEU. The impact of trade on domestic activities of Kyrgyzstan and Belarus is indeed significant. Their trade openness indices are twice as high as those of the other three EAEU members. It is necessary to point out the positive dynamics of the TOI indicators in the example of Belarus, while an inverse trend was observed for Kyrgyzstan. With the lowest TOI, Russia ranks last in terms of openness to trade among members of the EAEU.

Although Armenia's GDP per capita is half that of Russia, the Armenian trade openness index is increasing steadily, approaching the value of 100 . One of the challenges Armenia and Kyrgyzstan face in their bilateral trade relations is their similarity: both countries export large amounts of metal ore and workforce. Another complicating factor for Armenia is the closure of its borders with two neighbouring countries, Turkey and Azerbaijan, which has been stifling its economy for decades.

Figure 5 shows the share of exports in the GDP of the EAEU countries in the period from 2014 to 2018. 
Figure 5 Share of exports in GDP(EGDP) for the EAEU countries, 2014-2018

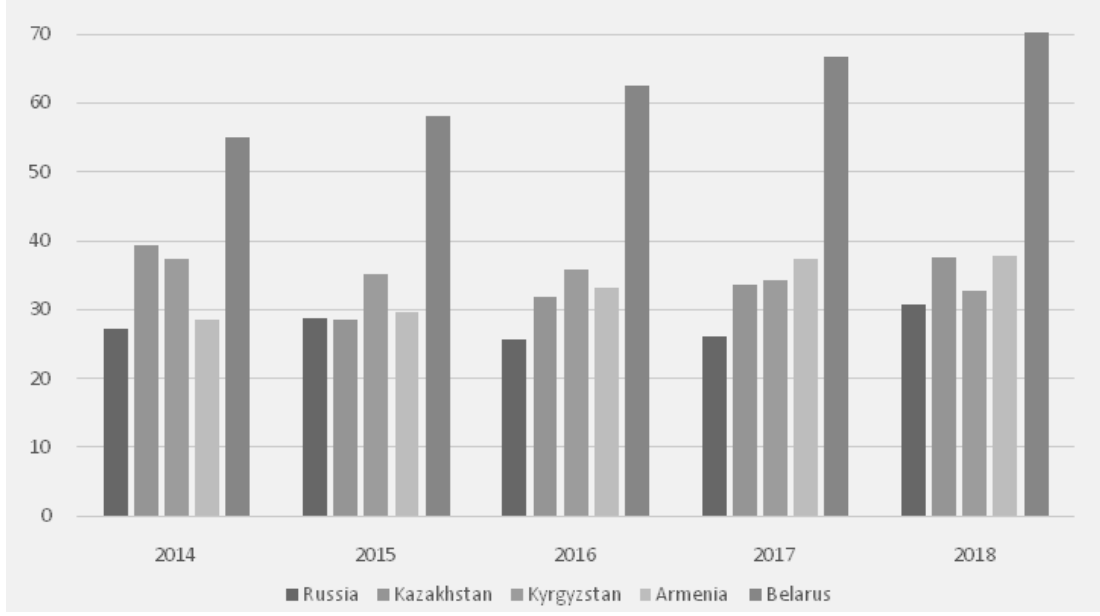

Source: Author's representation according to the World Bank statistical database (2020) data

Figure 5 shows varying export expansion of the EAEU member states. In other words, exports make up about 25 to $40 \%$ of the GDP of Russia, Kazakhstan, Kyrgyzstan and Armenia. It should be noted that Armenia and Russia recorded a similar level of export expansion. However, the situation in Belarus is different. Belarus' exports accounted for approximately $55 \%$ of GDP in 2014 , and by 2018 , that number had risen to an impressive $70 \%$. It needs to be highlighted that during the observed period only Belarus recorded export expansion.

\section{Conclusion}

The Eurasian Economic Union (EAEU) was founded in 2015 and currently has five members: Belarus, Kazakhstan, Russia, Kyrgyzstan and Armenia. The paper analyses the openness to foreign trade of the five member states of this political and economic alliance. The analysis uses the following indicators: intra-industry trade (IITR), import content of exports (EXIM), foreign trade balance (TBAL), and the share of exports in GDP (EGDP). The reference period is from 2014 to 2018 . The analysis of the obtained results for these indicators confirm the primary hypothesis of the paper, which assumes differences in trade openness and export orientation between the EAEU member states.

The conclusion is that EAEU member states differ significantly when it comes to international trade, rapid growth of export, and trade openness. Russia, Belarus and Kazakhstan show higher levels of trade integration, while Kyrgyzstan and Armenia have room for progress when it comes to foreign trade. It should be added that despite its dominant role in trade within the EAEU, Russia is the least dependent on the EAEU alliance.

Capital flows and workforce movement from/to the smaller economies of the EAEU are mainly concentrated around Russia. One of the assumptions is that as the EAEU develops, smaller countries would seek to target a much larger Russian market instead of expanding their mutual trade. For example, free movement of the workforce is of great benefit to Armenia and Kyrgyzstan. Migrants from Armenia and Kyrgyzstan working in Russia send home billions of USD every year. However, from a trade point of view, the EAEU represents a considerable advantage for Russia's foreign trade with other member states.

Between 2014 and 2016, there was an evident economic downturn in the EAEU alliance caused by falling global energy prices and Western sanctions on Russia following the annexation of Crimea. As evident from the data presented, such a situation has led to a decline in trade within the EAEU. The establishment of the EAEU alliance could be interpreted as Russia's reaction to the economic downturn and the search for alternative markets. EAEU member states have benefited from the removal of non-tariff barriers. Nevertheless, they have faced economic and political challenges that have significantly affected their foreign trade. However, it is important to emphasise once again that Russia holds significant economic and political power in the EAEU alliance. 


\section{REFERENCES}

1. Balassa, B. (1966). Tariff Reduction and Trade in Manufactures among Industrial Countries. American Economic Review, 56(3), 466-473.

2. Bhagwati, J. N. (2004). In Defence of Globalization. Oxford University Press.

3. Bezić, H. \& Galović, T. (2014). The International Trade of European Chemical Industry. In Antončić, B. (Ed.). Proceedings of Advances in Business-Related Scientific Research Conference - ABSRC 2014. Milan: GEA COLLEGE - Faculty of Entrepreneurship.

4. EAEUNION (2020). Eurasian Economic Union - about. http://www.eaeunion.org/?lang=en\#aboutinfo

5. Fujii, E. (2017). What Does Trade Openness Measure? (CESifo Working Paper No. 6656). Munich: Munich Society for the Promotion of Economic Research.

6. Galović, T., Mišević, P. \& Popović, L. (2017). The Export Competitiveness of EU28 Countries. In Baković, T. et al. (Eds.), TRADE PERSPECTIVES 2017 Specialisation and Customer-Centred Retailing (pp. 15-31). Faculty of Economics Zagreb \& Croatian Chamber of Economy.

7. Galović, T., Bezić, H. \& Primorac, D. (2018). The Export Competitiveness of NAFTA Countries. In Cingula, M. et al. (Eds). Proceedings of the 31st International Scientific Conference on Economic and Social Development - "Legal Challenges of Modern World" (pp. 493-502). Split: Varaždin Development and Entrepreneurship Agency.

8. Grubel, H. G. \& Lloyd, P. J. (1975). Intra-industry Trade: The Theory and Measurement of International Trade in Differentiated Products. The Macmillan Press Ltd.

9. ICG (2020). The Eurasian Economic Union: Power, Politics and Trade. https://d2071andvip0wj.cloudfront.net/240-the-eurasian-economic-union-power-politics-and-trade.pdf

10. Kandžija, V., Bezić, H. \& Galović, T. (2014). The International Trade of EU Food, Beverages and Tobacco Sector. In Kandžija, V. \& Kumar, A. (Eds.), Economic System of European Union and Accession of Bosnia E Herzegovina (pp. 289-309). University of Rijeka - Faculty of Economics.

11. Kharroubi, E. (2011). The Trade Balance and the Real Exchange Rate. BIS Quarterly Review, September 2011. https://ssrn.com/abstract $=1953321$

12. Krugman, P. (1983). New Theories of Trade among Industrial Countries. American Economic Review, 73(2), 343-347.

13. Popescu, N. (2014). Eurasian Union: the real, the imaginary and the likely (Chaillot Paper No. 132). Paris: EU Institute for Security Studies.

14. Mardas, D. \& Nikas, C. (2008). European Integration, Intra-Industry Trade in Vertically Differentiated Products and the Balkan Countries. International Advances in Economic Research, 14(4), 355-368. https://doi.org/10.1007/s11294-008-9164-9

15. Mišević, P. (2019). Međunarodna trgovina zemalja članica OPEC-a. Poslovna izvrsnost - Business Excellence, 13(2), 223-237. https://doi.org/10.22598/pi-be/2019.13.2.223

16. Solow, R. M. (1956). A Contribution to the Theory of Economic Growth. Quarterly Journal of Economics, 70(1), 65-94. https://doi.org/10.2307/1884513

17. Van der Togt, T. (2015). From Competition to Compatibility. Striking a Eurasian balance in EU-Russia relations. Netherlands Institute of International Relations.

18. Vinokurov, E. \& Tsukarev, T. (2015). Agenda for the EEU Economy. Valdai Papers No. 25, pp. 1-15. https://ssrn.com/abstract $=2741016$

19. Vinokurov, E. (2014). The EDB System of Indicators of Eurasian Integration II. Report No. 22, Centre for Integration Studies, Eurasian Development Bank, Saint-Petersburg.

20. Wakasugi, R. (2007). Vertical Intra-industry Trade and Economic Integration in East Asia. Asian Economic Papers, 6(1), 26-45. https://doi.org/10.1162/asep.2007.6.1.26 